\title{
SPATIAL DISTRIBUTION AND MORPHOMETRY OF THE SUCCINEID SNAIL SUCCINEA BACONI (PFEIFFER, 1854) IN INDIA
}

\author{
Himangshu Barman ${ }^{\mathrm{a}, \mathrm{b}}$, Soujita Pramanik ${ }^{\mathrm{a}}$, Gargi Nandy ${ }^{\mathrm{a}}$, Sampa Banerjee ${ }^{\mathrm{a}}$ and Gautam Aditya ${ }^{\mathrm{a}^{*}}$
}

aDepartment of Zoology, University of Calcutta, 35 Ballygunge Circular Road, Kolkata 700019, India;

bepartment of Zoology, Ramnagar College, Depal, Purba Medinipur, 721453, West Bengal, India

*Corresponding author. Email: gautamaditya2001@gmail.com

\author{
Article history \\ Received: 12 April 2021; \\ accepted 24 September 2021
}

\section{Keywords:}

Land snail; Succinea

baconi; abundance; logistic regression; length-weight relationship

\begin{abstract}
The spatial distribution and morphological features of the land snail Succinea baconi (Pfeiffer, 1854) (Gastropoda: Succineidae) from India were evaluated. The survey performed in gardens and bushes in Coochbehar, West Bengal, India, has made it possible to assess the abundance of the snail $S$. baconi on the randomly selected lemon plants $(n=18)$. Logistic regressions were employed to judge differences in vertical distribution, resource association and size class variation in the snails under study. Variation in shell morphology was assessed by performing the regression analysis of the sampled shells of live snails $(\mathrm{n}=258)$ and vacant shells of the deceased individuals $(\mathrm{n}=100)$. An overall significant difference $(p<0.05)$ in the vertical distribution of snails in lemon plants was observed. As to their association with resources available, snails were found to be more abundant in detritus than on living parts of the plants. The performed logistic regression revealed that the relative abundance of different $S$. baconi size classes was significantly different $(p<0.001)$. Significant correlations $(p<0.001)$ were found among different body size variables, with the shell length (x)-body weight (y) relationship being: $\mathrm{y}=0.232 \mathrm{x}^{2.524}$ (for live snails) and the shell length (x)-shell weight (y) relationship being: $y=0.358 \mathrm{x}^{2.537}$ (for shells of dead snails). Various parameters of the snail shell shape could be represented through regression equations. Although reproduction and growth strategies of snails need to be explored further, the presented observations improve our understanding of the ecology of $S$. baconi, which may prove useful for future conservation efforts.
\end{abstract}

\section{INTRODUCTION}

Land snails play an important role in terrestrial communities, exhibiting substantial variations in shape, size and colour among species (Panha and Burch 2005; Raheem and Naggs 2006; Ramakrishna et al. 2010; Raheem et al. 2014). Among diverse land snails, micro-land snails are miniscule in size and occur in high abundances in certain habitats (Panha and Burch 2005). The habitats exploited by small land snails include detritus laden soil, as well as stems, bark, leaves and canopy of trees. The wide range of resources used by small land snails in these habitats allows classifying and characterizing them as herbivorous, detritivorous and predatory species (Raut and Ghose 1984a; Raheem and Naggs 2006; Sarma et al. 2007; Sen et al. 2012; Nandy et al. 2019). In many instances, small land snails cause the destruction of economically important crops and vegetables, and are therefore considered as pests (Raut and Ghose 1984a; Das et al. 1989; Barker 2002; Wilson 2007; Avhad et al. 2013). On a worldwide scale, studies on biology, ecology and diversity of small land snails highlight their ecological roles and the ecosystem services they provide (Barker 2001, 2002; Raheem and Naggs 2006; Ramakrishna et al. 2010; Raheem et al. 2014; Budha et al. 2015).
Bearing in mind the diversity of land snails (Ramakrishna et al. 2010; Raheem et al. 2014; Sajan et al. 2021 ) in the Indian context, the number of studies performed on biology and ecology of individual species is still limited. The information on such species as Achatina fulica (Raut 1979, 1999; Raut and Barker 2002), Cryptaustenia ovata (Saha and Roy 1994; Avhad et al. 2013), Macrochlamys indica (Raut 1979), Allopeas gracile (Raut 1984; Sarma et al. 2007), Indosuccinea semiserica (Raut and Ghose 1984b; Raut 1986) and Succinea daucina (Raut et al. 1997) reflects diverse ecological roles of terrestrial snails in India. During the survey of land snails associated with the vegetation of northern part of West Bengal, India, a chance encounter with the succineid snail Succinea baconi (Pfeiffer, 1854) (Gastropoda: Succineidae) prompted us to carry out the assessment of the distribution and shell morphology of this species.

Observations of the distribution and pestiferous nature of $S$. costaricana on the ornamental plants Dracaena marginara and D. deremensis in Costa Rica (Villalobos et al. 1995) and the distribution of $S$. thaanumi in Hawaii, USA (Rundell and Cowie 2003) indicate that succineid snails show preference for arboreal habitats. In India, other species, e.g., S. daucina, are observed mostly in moist soil (Raut et al. 1997). A variety of other 
small snail species including the citrus tree snail Drymaeus dormani (Bledose and Minnick 1982), Euhadra amaliae (Watada and Wada 1996, 1998), Sitala jenynsi (Kasigwa 1999a,b), Boninosuccinea ogasawarae and B. punctulispira (Sugiura 2011), Satsuma (Luchuhadra) eucosmia eucosmia (Takeuchi and Takeda 2016) use trees as habitat. In India, as observed in the southern region of West Bengal (Raut and Ghose1984b), succineid snails such as I. semiserica exhibit preference for lemon plants (Citrus limon).

The heterogeneity in snail sizes can be represented through the shell length and body weight, which vary with the ontogeny and age (Baur 1984; Goodfriend 1986; Hawkins et al. 1997; Preston and Roberts 2007). Using the shell length and body weight regression equations, the size and shape variability of aquatic snails (Palmer 1982; Tokeshi et al. 2000; Mckinney et al. 2004; Elkarmi and Ismail 2007; Saha et al. 2016) as well as that of terrestrial snails (Hawkins et al. 1997; Preston and Roberts 2007; Okon et al. 2012) is described as a universal rule. On the other hand, the morphology and life history traits, e.g., body size and fecundity, are considered to be crucial parameters for understanding the colonization and spread of snails (Cameron and Cook 1989; Carvalho et al. 2008).

The purpose of the present study was to record the distribution and the relative abundance of $S$. baconi as well as to give the appraisal of its morphological features based on field-collected specimens. The abundance and distribution of $S$. baconi will provide information on its habitat preferences and functional relevance in the terrestrial ecosystem. The correspondence between different morphological variables will reflect the size and shape characteristics as well as population buildup of the snail S. baconi in the concerned habitats. The information will be useful in predicting the possibilities of colonization and establishment of a stable population of S. baconi in similar habitats in India.

\section{MATERIALS AND METHODS}

\section{Study sites}

The study was carried out in Coochbehar, West Bengal, India (Figure 1). Habitats such as semi managed gardens, bushes, grass lands, and decaying surfaces were surveyed biweekly during the monsoon and post monsoon seasons (July to November) of 2015 and 2016. The survey timing was chosen based on the previous research observations where land snail encounter rates were found to be higher during the wet weather (Raut and Ghose 1984a, b; Raut et al. 1997). In a particular habitat, a $10 \times 10 \mathrm{~m}^{2}$ area covered with highly heterogeneous vegetation, including grasses and lemon trees (C. limon), was surveyed. The diameter of the $2 \mathrm{~m}^{2}$ area around a lemon tree was additionally surveyed for the presence of the snails using appropriate methods (Sturm et al. 2006).

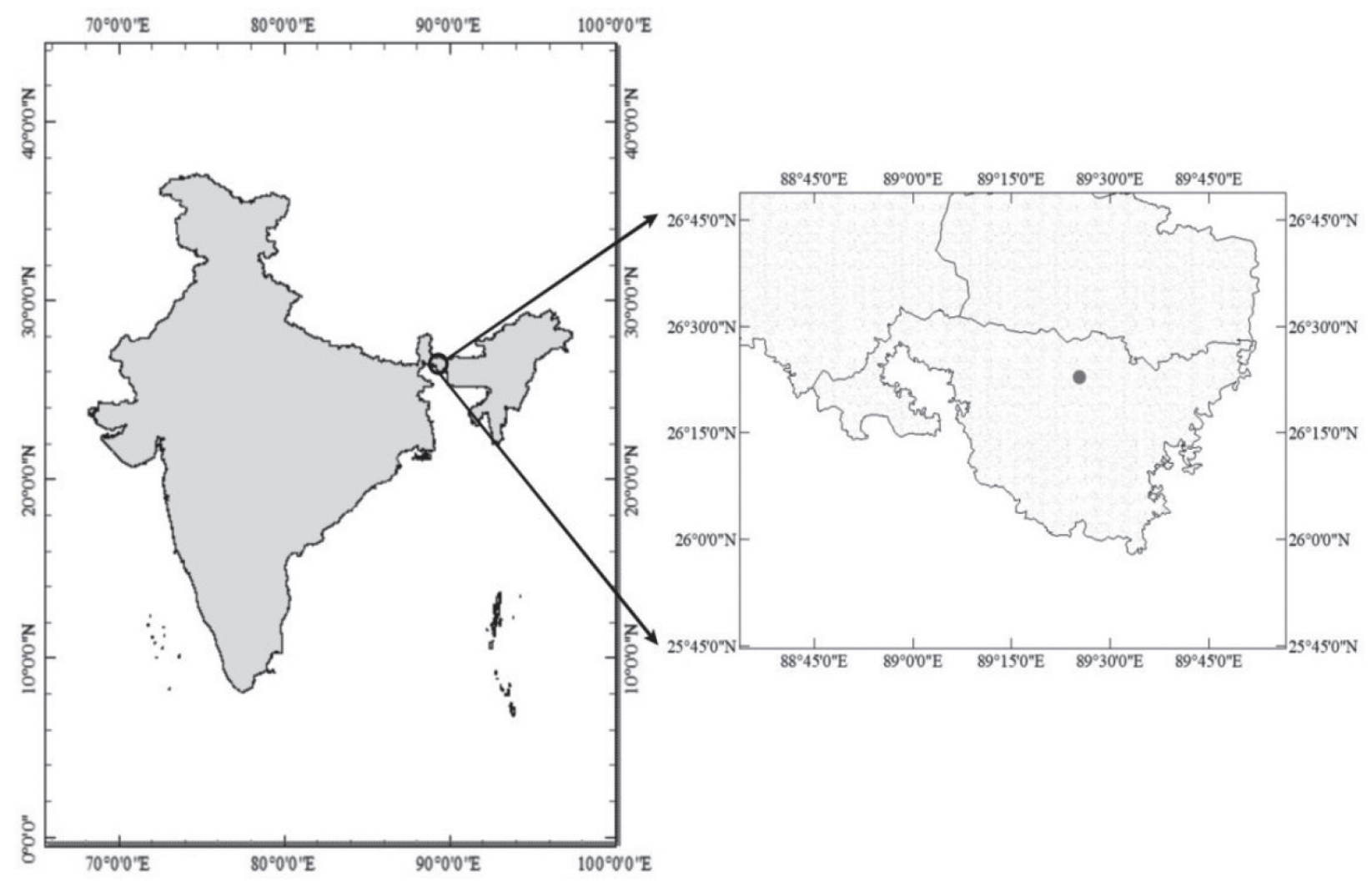

Figure 1. Map of the study area in India highlighting the district of Coochbehar, West Bengal, India. 


\section{Assessment of abundance and size of S. baconi}

The sampling and survey work was carried out following stratified random sampling methods (Ludwig and Reynolds 1988), i.e., a study plant and a study area were chosen at random, with sampling from the same place being repeated for at least three times within the sampling period, so that the samples could qualify as replicates (Hurlbert 1984). The identification of snails was performed in accordance with appropriate keys (Rao 1924; Ramakrishna et al. 2010). The following characteristics were considered (Ramakrishna et al. 2010): very thin and semiovately acuminate shell, whorls $2 \frac{1}{2}$, a very short spire compared to the bodywhorl, the last whorl globex, aperture acuminately oval, peristome thin, which is absent in other succineids of India (Gude 1914; Raheem et al. 2014).

The live snails collected from the leaf litter and lemon were kept in separate plastic containers $(100 \mathrm{~mL}$, Tarsons ${ }^{\circledR}$, India) according to the collection site and time of collection. The container was supplied with the tissue paper dipped in water to maintain the relative humidity $>80 \%$. In the laboratory, the collected snails were emptied in a plastic container $(32 \times 36 \times 38 \mathrm{~cm})$ containing soil layer for rearing and maintenance. The snails collected during each sampling effort were categorized into different size classes according to their shell length (in $\mathrm{mm}$ ). The number of specimens falling into each size class was recorded. With a class interval of $1 \mathrm{~mm}$, 8 size classes of snails were formed (according to the shell length, which varied from $1 \mathrm{~mm}$ to $9 \mathrm{~mm}$ ).

Each lemon tree within a sampling quadrat was surveyed from the base to the top. The live snails detected at a particular height of the lemon tree were collected and placed in to separate specimen containers (Kasigwa 1999a, b). The average height of the examined lemon trees was $120 \mathrm{~cm}$. The vertical sections of the trees were classified as $\mathrm{L}$ - the lower most section of the stem - from the ground surface to $30 \mathrm{~cm}$ in height, $\mathrm{ML}$ - the middle lower section - from 31 to $60 \mathrm{~cm}$ in height, MU - the middle upper section-from 61 to $90 \mathrm{~cm}$ in height and the Top - from 91 to $120 \mathrm{~cm}$ in height, i.e., to the highest leaf of the main shoot of the plant. Data on the distribution of live snails from different heights of the examined lemon trees were recorded and used for analysis.

The data on the collected S. baconi specimens based on the vertical distribution, association with the detritus and leaves and size class wise variations were subjected to statistical analysis based on a binomial generalized linear model with logit link (McCullagh and Nelder 1989; Fox 2008). A typical expression of the logistic regression (binomial GLM) in the form of: $y$ (response variable) $=1$ / $(1+\exp (-(-a+b x)))$, was used to deduce the relationship between the snail abundance (response variable) against the explanatory variable $(\mathrm{x}$; representing the vertical height or the resource or the size class as applicable, re- spectively). A binary sum form of the response variable was used, and the parameters of the model were estimated through the maximum likelihood method using XLSTAT software, release 10 (Addinsoft 2010). The parameters of the model ( $a$ and $b$ ) were tested for significance employing a chi-square method (McCullagh and Nelder 1989; Fox 2008). Application of the logistic regression was based on the assumption that the relative abundance of $S$. baconi on the lemon tree and in associated habitats follow a binomial $(n, p)$ distribution with $n$ observations for each of the explanatory variables (whether size class, vertical distribution or resource). The probability parameter shown as $p$, is assumed to be a linear matching of the explanatory variables. Significant contribution of the explanatory variables to the distribution of $S$. baconi was inferred from the logistic regressions.

\section{Morphometric analysis}

In this study, assessment of $S$. baconi morphology was based on the shell shape and body weight relationship. For that purpose, we used field-collected live snails and shells of the deceased ones, which were collected from the same habitats. In order to estimate the shell shape, the measurements of the shell length (SL), shell breadth (SB), spire ratio (SR), shell aperture length (AL), shell aperture breadth $(\mathrm{AB})$ and the body weight $(\mathrm{BW})$ of live snails were analyzed. The shell length (from the apex to the tip of the last whorl in mm) and shell breadth (width of the last whorl) were measured using a vernier caliper (Insize, Brazil) and were recorded to the nearest $0.1 \mathrm{~mm}$. The body weight (dry weight) of a live snail specimen was recorded using a pan balance (Citizen, India) to the nearest $0.1 \mathrm{mg}$. Shell weights of the dead snails were recorded in a similar way.

A regression analysis (Zar 1999) was performed to establish the relationship among the variables representing the body size of snails. Thus, the shell length (SL in $\mathrm{mm}$ ), shell breadth (SB in $\mathrm{mm}$ ), and the body weight (BW in $\mathrm{mm}$ ) of live S. baconi (258 specimens) were assessed for that purpose. The extrapolation of the regression (power) equation between the length and weight of shells of dead (snails (100 specimens), was used to deduce the soft tissue weight $\left(\mathrm{W}_{\mathrm{ST}}\right.$, in $\mathrm{mg}$ ) of live snails. The shell weight of live snails $\left(\mathrm{W}_{\mathrm{SH}}\right.$, in $\mathrm{mg}$ ) was deduced by subtracting the soft tissue weight from that of the body. Although used for shells with a conical shape, the apical angle, AA (Preston and Roberts 2007), was evaluated as a feature for describing the shape of the apex of the snail $S$. baconi using the following formula: $\mathrm{AA}^{\circ}=2 *(\tan (0.5 \times \mathrm{SB} / \mathrm{SL}))$. In all instances, a live snail, which was considered for the estimation of the morphometry, was not subsequently considered as dead so as to avoid the possibility of pseudoreplication (Hurlbert 1984). To comply with the norms of replication, live snails and shells of the dead ones were collected at different times and from different habitats. 


\section{RESULTS}

There was a large number of live snails $(\sim 258)$ recorded on lemon plants $(\mathrm{n}=18)$ over the study periods July-September 2015 and July-September 2016. The examination of the vertical distribution of live $S$. baconi individuals on lemon plants showed that in the lower most (L) (mean $8.29 \pm 2.67 \mathrm{SE}$ ) and the middle lower (ML) (mean $8.43 \pm$ $3.71 \mathrm{SE}$ ) sections of the plants, snails were the most numerous, their numbers in the middle upper (MU) (mean $5.86 \pm 2.98 \mathrm{SE}$ ) and top (T) (mean $3.57 \pm 2.08 \mathrm{SE}$ ) parts, being lower. Overall significant differences in numbers of snails recorded in the lower most (L), middle lower (ML), middle upper (MU) and the top parts of plant are represented through logistic regression (Figure 2a). As is evident from the logistic regression: abundance (y) $=1 /\left(1+\exp \left(-\left(-2.00+0.35^{*}\right.\right.\right.$ vertical height $\left.\left.)\right)\right)$, where the parameters of the equation remained statistically

(a)

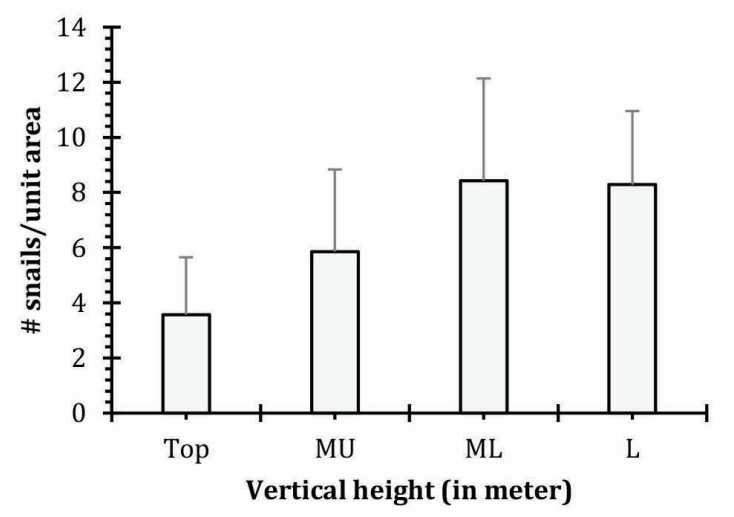

(c)

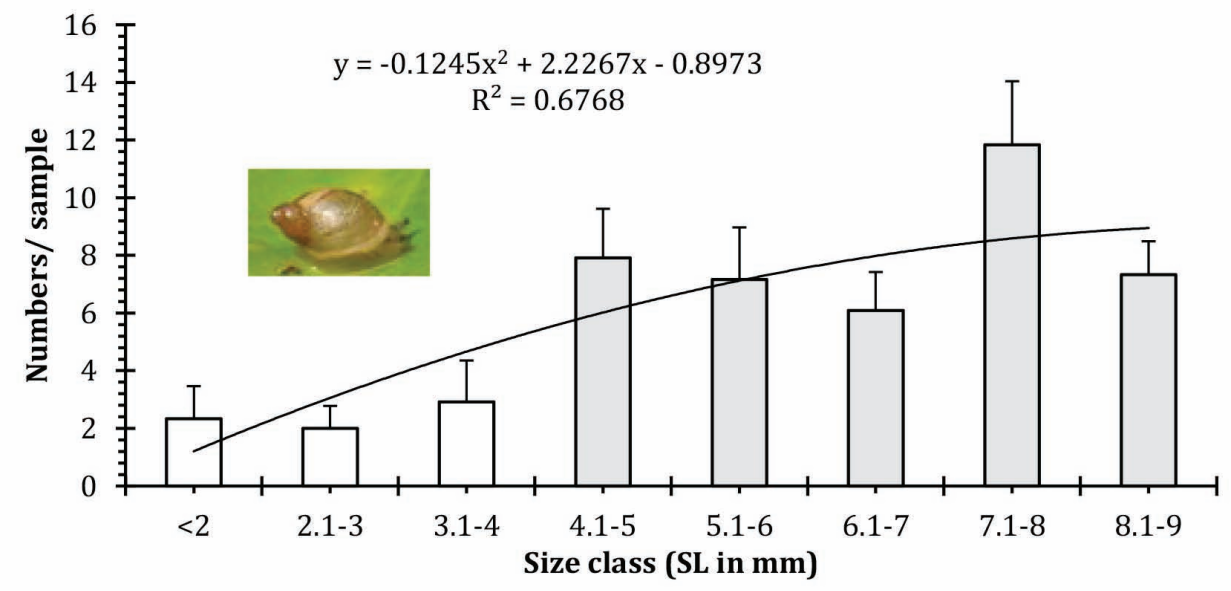

Figure 2. (a) The distribution of the snail S. baconi on lemon plants in the study area. The average height of the plants was $120 \mathrm{~cm}$ with the vertical strata being classified as L - the lower most portion of the stem - from ground to the height of $30 \mathrm{~cm}, \mathrm{ML}$ - the middle lower portion-from 31 to $60 \mathrm{~cm}$ in height, MU - the middle upper portion- from 61 to $90 \mathrm{~cm}$ and the top portion - from 91 to $120 \mathrm{~cm}$ in height, i.e., to the highest leaf of the main shoot of the plant. Occurrence of snails at respective height intervals significantly varied and could be represented through logistic regression. (b) The preferred habitat resources, detritus includes dead leaves, twigs and branches of lemon tree, while green twigs and leaves are considered as leafage. Here the triangle represents the mean value and the horizontal bar the median value. (c) The size class-based distribution of the snails collected from the habitats. The first three bars represent juvenile size classes, and the shaded bars the reproductive size ones. 0.001 ; vertical height $=0.35 \pm 0.08$; Wald's $\chi^{2}=19.332$; $p<0.001$ ), the vertical distribution of snails at different heights of plants remained uneven with the majority of snails recorded at a height between 20 and $60 \mathrm{~cm}$ from the ground surface.

In this study, the abundance of snails on plants was found to vary not only with tree height, but also with the resources available, i.e. green plant parts (leaves) (mean $4.0 \pm 0.65 \mathrm{SE}$ ) and detritus (dead leaves, twigs and branches) (mean $6.75 \pm 1.46$ ). For snails, detritus appeared to be preferable to leaves (Figure 2b). The logistic regression, abundance $(y)=1 /(1+\exp (-(-$ $2.97-0.53 *$ resource $))$ ) explained the difference in the abundance of $S$. baconi by differences in the resources available with the parameters of the equation remaining statistically significant (intercept $=-2.97 \pm 0.20$; Wald's $\chi^{2}=218.45 ; p<0.001$; resource $=-0.53 \pm 0.15$;

(b)

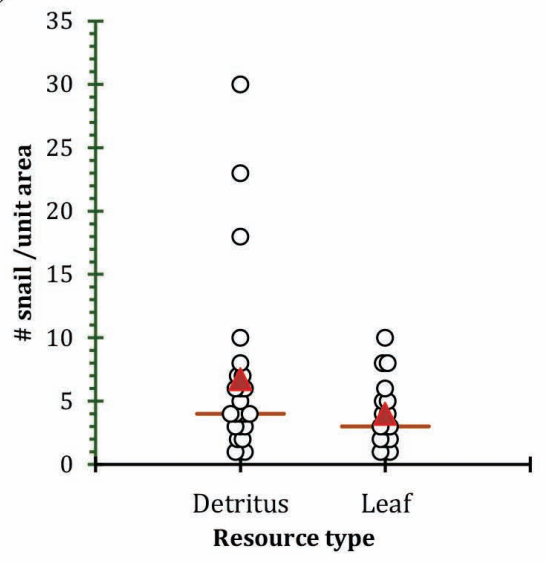

significant (intercept $=2.00 \pm 0.23$; Wald $\chi^{2}=74.9 ; p<$ 
Wald $\left.\chi^{2}=13.312 ; p<0.001\right)$. Thus, differences in snail abundance were mostly associated with detritus and hardly with leaves. In addition, differences in the relative abundance of collected snails were also observed in their respective size classes.

Differences in the proportional abundance of different snail size classes (Figure 2c) could be related as: abundance $(y)=1 /(1+\exp (-(-3.04+0.22 *$ size class $)))$ with the parameters of the equation remaining significant (intercept $=3.04 \pm 0.12$; Wald's $\chi^{2}=637.61 ; p<0.001$; size class $=0.22 \pm 0.02$; Wald $\chi^{2}=637.61 ; p<0.001$ ). The morphological features presented in Table 1 show the heterogeneity of the $S$. baconi population. Live snails were found to vary in their shell length and body weight more than shells of the dead individuals. The calculated apical angle of the shells remained $0.67 \pm$ 0.01 (Mean $\pm \mathrm{SE}$ ). The correlations among these variables (Table 2) and the regression of the shell length and the body weight of live $S$. baconi (sample size of 258 live specimens) remained significant (Figure 3). The relationship between the body weight and shell length was: Body weight $(\mathrm{y})=0.164 *$ Shell length $(\mathrm{x})^{2.769} ; \mathrm{R}^{2}=$ 0.924. Using an extrapolation of the regression (power) equation between the shell length and shell weight of dead snails (100 specimens, Shell weight $(y)=0.04 *$ Shell length $(x)^{2.537} ; \mathrm{R}^{2}=0.897$, Figure $\left.3 \mathrm{~b}\right)$, and by comparing it with the regression of the shell length and body weight of live snails, the weight of the soft tissue

Table 1. Values of morphological features and body weight of the snail S. baconi, live snails $(\mathrm{n}=258)$ as well as shells of dead specimens $(n=100)$. The weight of the shell and that of the soft tissue are the derived variables deduced from the extrapolation of the shell length and shell weight equation shown in Figure 3.

\begin{tabular}{|c|c|c|c|c|c|c|}
\hline \multicolumn{7}{|c|}{ Live snails $(\mathrm{n}=258)$} \\
\hline $\begin{array}{l}\text { Body weight } \\
\text { (BW in } \mathrm{mg} \text { ) }\end{array}$ & $\begin{array}{l}\text { Shell length } \\
(\mathrm{SL} \text { in } \mathrm{mm})\end{array}$ & $\begin{array}{l}\text { Shell breadth } \\
\text { (SB in } \mathrm{mm})\end{array}$ & \multicolumn{2}{|c|}{$\begin{array}{l}\text { Aperture length (AL } \\
\text { in } \mathrm{mm})\end{array}$} & \multicolumn{2}{|c|}{$\begin{array}{l}\text { Aperture breadth } \\
\text { (AB in mm) }\end{array}$} \\
\hline $\begin{array}{c}1.9-91.5 \\
19.97 \pm 1.12\end{array}$ & $\begin{array}{c}2.3-9.2 \\
5.23 \pm 0.09\end{array}$ & $\begin{array}{c}1.9-5.1 \\
3.26 \pm 0.05\end{array}$ & \multicolumn{2}{|c|}{$\begin{array}{c}1.9-5.1 \\
3.63 \pm 0.06\end{array}$} & \multicolumn{2}{|c|}{$\begin{array}{c}1.3-4.3 \\
2.7 \pm 0.04\end{array}$} \\
\hline $\begin{array}{l}\text { Spire ratio } \\
\quad(\mathrm{SR})\end{array}$ & $\begin{array}{c}\text { Apical angle } \\
\left(\mathrm{AA}^{\circ}\right)\end{array}$ & \multicolumn{2}{|c|}{$\begin{array}{c}\text { Weight of shell ( } \mathrm{W}_{\mathrm{SH}} \text { in } \mathrm{mg} \text { ) } \\
\text { (derived) }\end{array}$} & \multicolumn{3}{|c|}{$\begin{array}{c}\text { Weight of soft tissue }\left(\mathrm{W}_{\mathrm{ST}} \text { in } \mathrm{mg} \text { ) }\right. \\
\text { (derived) }\end{array}$} \\
\hline $\begin{array}{l}1.15-2.13 \\
1.59 \pm 0.01\end{array}$ & $\begin{array}{c}0.48-0.93 \\
0.67 \pm 0.01\end{array}$ & \multicolumn{2}{|l|}{$\begin{array}{c}0.3-9.97 \\
2.76 \pm 0.12\end{array}$} & \multicolumn{3}{|c|}{$\begin{array}{r}1.37-82.59 \\
17.23 \pm 1.01\end{array}$} \\
\hline \multicolumn{7}{|c|}{ Shells of dead snails $(\mathrm{n}=100)$} \\
\hline $\begin{array}{l}\text { Shell weight } \\
\text { (SW in } \mathrm{mg} \text { ) }\end{array}$ & $\begin{array}{l}\text { Shell length } \\
\text { (SL in mm) }\end{array}$ & $\begin{array}{l}\text { Shell breadth } \\
\text { (SB in mm) }\end{array}$ & $\begin{array}{r}\text { Aper } \\
\text { (A }\end{array}$ & $\begin{array}{l}\text { ture length } \\
\mathrm{L} \text { in } \mathrm{mm})\end{array}$ & $\begin{array}{l}\text { Aperture breadth } \\
(\mathrm{AB} \text { in } \mathrm{mm})\end{array}$ & Spire Ratio (SR) \\
\hline $\begin{array}{l}0.31-12.38 \\
2.97 \pm 0.28\end{array}$ & $\begin{array}{c}2.2-9.2 \\
5.14 \pm 0.17\end{array}$ & $\begin{array}{c}1.1-4.9 \\
2.32 \pm 0.09\end{array}$ & & $\begin{array}{l}1.8-7.1 \\
03 \pm 0.14\end{array}$ & $\begin{array}{c}1.2-4.9 \\
2.69 \pm 0.08\end{array}$ & $\begin{array}{c}1.63-3.46 \\
2.26 \pm 0.04\end{array}$ \\
\hline
\end{tabular}

Table 2. Values of the Pearson's product moment correlation coefficient, $r$, for the paired variables [BW - body weight, SL shell length, $\mathrm{SB}$ - shell breadth, $\mathrm{AL}$ - aperture length, $\mathrm{AB}$ - aperture breadth, $\mathrm{W}_{\mathrm{SH}}-$ weight of shell (derived), $\mathrm{W}_{\mathrm{ST}}-\mathrm{weight}$ of soft tissue, SR - spire ratio, $\mathrm{SW}$ - shell weight and $\mathrm{AA}^{\circ}$ - apical angle]. The weight of the shell and the weight of the soft tissue are the derived variables deduced from the extrapolation of the shell length and shell weight equation shown in Figure 3. Values in bold are significant at $p<0.001$ level.

\begin{tabular}{|c|c|c|c|c|c|c|c|c|}
\hline \multicolumn{9}{|c|}{ (Living snails) } \\
\hline Variables & BW & SL & SB & $\mathrm{AL}$ & $\mathrm{AB}$ & $\mathrm{W}_{\mathrm{SH}}$ & $\mathrm{W}_{\mathrm{ST}}$ & SR \\
\hline SL & 0.908 & & & & & & & \\
\hline SB & 0.841 & 0.914 & & & & & & \\
\hline $\mathbf{A L}$ & 0.877 & 0.948 & 0.893 & & & & & \\
\hline $\mathbf{A B}$ & 0.846 & 0.916 & 0.876 & 0.914 & & & & \\
\hline $\mathbf{W}_{\mathrm{SH}}$ & 0.950 & 0.975 & 0.882 & 0.923 & 0.892 & & & \\
\hline $\mathbf{W}_{\mathrm{ST}}$ & 0.999 & 0.894 & 0.830 & 0.865 & 0.834 & 0.937 & & \\
\hline SR & 0.476 & 0.594 & 0.230 & 0.509 & 0.466 & 0.562 & 0.462 & \\
\hline $\mathbf{A A}^{\circ}$ & -0.471 & -0.607 & -0.259 & -0.522 & -0.485 & -0.558 & -0.456 & -0.985 \\
\hline \multicolumn{9}{|c|}{ (Shell of dead Snails) } \\
\hline Variables & SW & SL & SB & $\mathrm{AL}$ & & & & \\
\hline SL & 0.898 & & & & & & & \\
\hline SB & 0.842 & 0.900 & & & & & & \\
\hline AL & 0.898 & 0.973 & 0.878 & & & & & \\
\hline AB & 0.862 & 0.925 & 0.821 & 0.930 & & & & \\
\hline
\end{tabular}


$\left(\mathrm{W}_{\mathrm{ST}}\right)$ was obtained. Morphological variables including the shell length/ shell breadth ratio were significantly positively correlated (Figure 3c), as indicated by values of the Pearson product moment correlation coefficient, (r). Regression equations for the relationship among different variables are shown in Figure 4. In all the paired variables in the regression equation, high values of coefficient of determination $\left(\mathrm{r}^{2}\right)$ were observed, except for the relation of the apical angle with the shell length and the body weight respectively.

\section{DISCUSSION}

The vertical distribution of $S$. baconi snails on lemon trees varied considerably, which is, perhaps, due to the disparity in the availability of food resources or oviposition sites as observed in different arboreal snails (Craig 1972; Kasigwa 1999a, b; Sugiura 2011; Takeuchi and

(a)

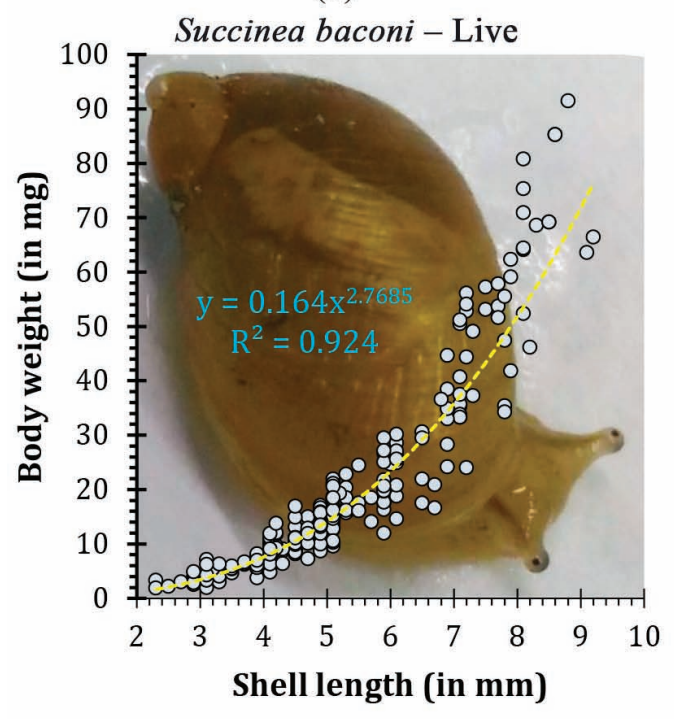

(c)

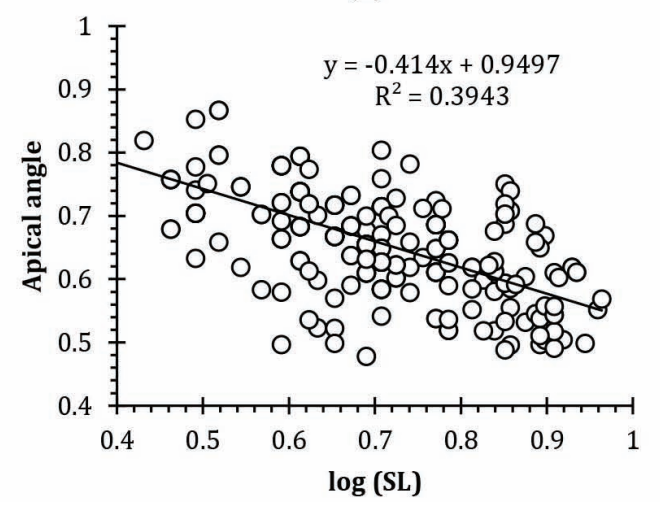

Takeda 2016). Arboreal snails including Succineidae feed on a wide range of resources such as fungi, algae, lichens, decaying plant materials, green plants and fruits (Sugiura 2011; Takeuchi and Takeda 2016). The distribution and abundance of $S$. baconi varied in different parts of the lemon tree. Most specimens were observed grazing branches and stems, with the maximum number of their occurrences recorded at small branching points where detritus is found. Although sparse in density, a few snails were observed at the base of lemon trees near the soil, where the deposition of dead leaves, twigs and stems allowed aggregation, as observed in S. costaricana (Villalobos et al. 1995). Compared to the distribution of the amphibious $S$. daucina (Raut et al. 1997), the distribution of $S$. baconi was mostly restricted to trees, and thus, it was observed crawling along tree branches and leaves as reported for B. ogasawarae and B. punctulispira (Sugiura 2011), E. amaliae (Watada and Wada 1996, 1998), S. jenynsi (Kasigwa 1999a, b),

(b)

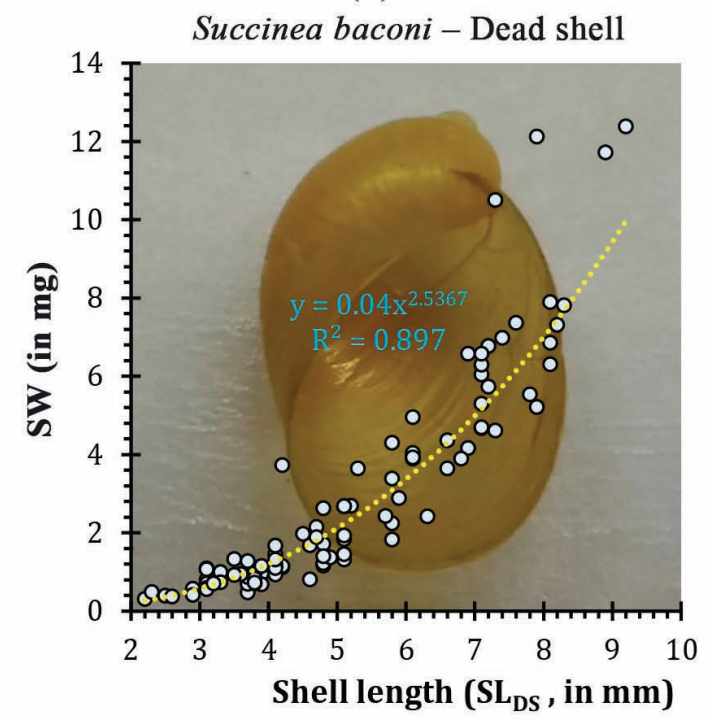

(d)

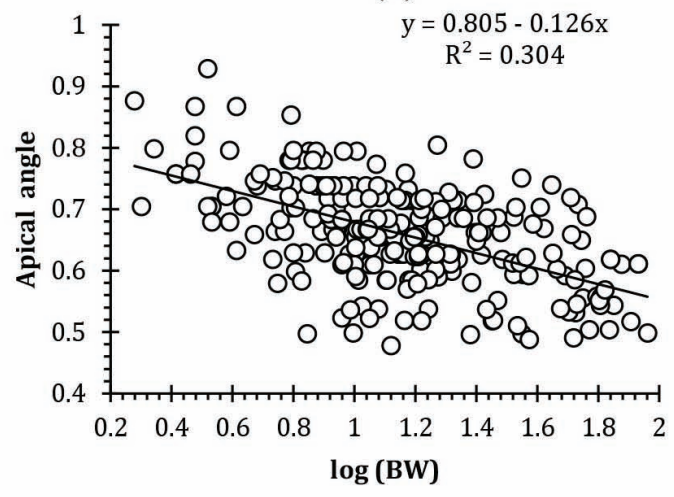

Figure 3. Relationship between the shell length and body weight of the live (a) and dead (b) individuals of S. baconi collected from gardens in and around Coochbehar, West Bengal, India in June-September, 2016. Data on the 258 live snails and the 100 shells of dead snails collected from the field were considered for analysis. The apical angle of the shells as a function of (c) the log of shell length (SL) and (d) the log of body weight (BW) are shown with the respective coefficient of determination. SW - Weight of shell of dead snails. 

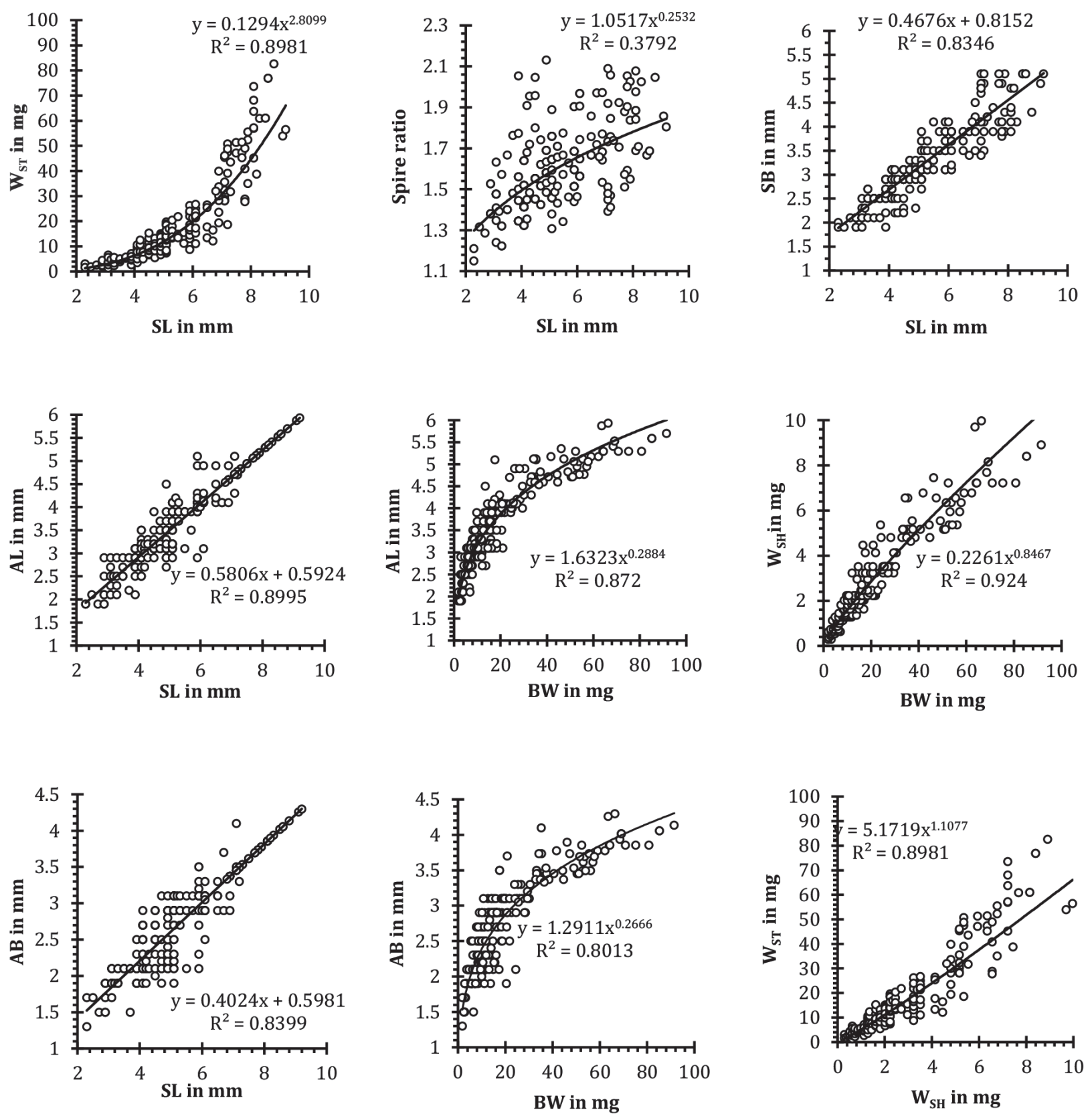

Figure 4. Relationship between paired variables of the shell and body size of the arboreal snail S. baconi considered in the present study. SL - shell length in mm, SB - shell breadth in $\mathrm{mm}, \mathrm{BW}$ - body weight of live snails in $\mathrm{mg}, \mathrm{W}_{\mathrm{SH}}-$ weight of shell in $\mathrm{mg}$, $\mathrm{W}_{\mathrm{ST}}$ - weight of soft tissue in $\mathrm{mg}, \mathrm{AL}$ - aperture length in $\mathrm{mm}, \mathrm{AB}$-aperture breadth in $\mathrm{mm}, \mathrm{SR}$ - spire ratio= shell length/ shell breadth. Data on the 258 live specimens and the 100 dead shells collected from the field were considered for analysis.

and S. (L.) eucosmia eucosmia (Takeuchi and Takeda 2016). Similar to B. ogasawarae and B. punctulispira (Sugiura 2011), S. baconi moves along tree branches in search of fungi, algae and lichens on lemon plants. In contrast to the wide range of plants utilized by E. amaliae (Watada and Wada 1996, 1998), S. jenynsi (Kasigwa 1999a, b), and B. ogasawoarae and B. punctulispira (Sugiura 2011), S. baconi was mostly associated with lemon plants. On other plants such as Hibiscus rosa-sinensis (China rose), Nyctanthes arbor-tristis (jasmine), Musa acuminata (banana), Tabernaemontana divaricata (crape jasmine), and Curcuma longa (turmeric), which host such snails as M. indica, A. fulica and C. ovata, S. baconi was not observed. Perhaps, because of unfavourable habitat conditions or the presence of predators, the distribution of $S$. baconi was confined exclusively to lemon trees, which is more typical of the citrus tree snail Drymaeus dormani (Bledose and Minnick 1982). However, the distribution of $S$. baconi on other trees cannot be ruled out if the habitat quality provided by other plants is equally suitable.

It is a known fact that $S$. costaricana (Villalobos et al. 1995) is associated with detritus, and E. amaliae 
is reported to hibernate within fallen leaves (Watada and Wada 1996). The fact that the number of S. baconi snails associated with detritus is relatively higher than that of those associated with green leaves is perhaps a reflection of habitat preferences as observed in S. costaricana. In the present observation, the preferred height of snail distribution on lemon plants seems to vary between 30 and $90 \mathrm{~cm}$ above the ground surface, which, perhaps, coincides with the detritus availability in the mid height of the individual plants. However, the size class-based preference regarding plant height and detritus availability would have made the explanation of the observed distribution of $S$. baconi clearer. Nonetheless, as a pioneer effort, this study records the distribution of snails on lemon plants in an Indian context, which is comparable to the observations on S. putris in Lithuania (Šatkauskienè 2005), on S. costaricana in Costa Rica (Villalobos et al. 1995), and on S. thaanumi in the Hawaii, USA (Rundell and Cowie 2003).

The heterogeneity of the population was reflected through the differential representation in different $S$. baconi size classes. The size classes were represented through the shell length as a surrogate of the snail body size (Cain 1977; Stone 1996; Chiba 2005). On a spatial scale, the heterogeneity of the size class in snails is reflected through the corresponding variations in the shell length and body weight (Cameron and Cook 1989; Madec et al. 2003; Madec and Bellido 2007). Increase in the shell length (SL), shell breadth (SB) and body weight (BW) is a characteristic feature in snail ontogeny. Changes in snail morphology can be deduced through the relation between the shell length and body weight at different ages (Baur 1984; Goodfriend 1986; Hawkins et al. 1997; Preston and Roberts 2007). The shell length and body weight relationship is almost a universally accepted measure for representing the body size in aquatic (Palmer 1982; Tokeshi et al. 2000; McKinney et al. 2004; Elkarmi and Ismail 2007; Saha et al. 2016) as well as in terrestrial snails (Hawkins et al. 1997; Preston and Roberts 2007; Okon et al. 2012).

In the present study, both live and dead specimens were considered for the morphometric analysis of the body size of $S$. baconi. The relationship between the shell weight and shell length of dead snails was used to deduce the shell weight and the soft tissue weight of live snails (Palmer 1982; Saha et al. 2016). Although bivariate regression equations were assessed (Figs 2 and 3 ), it is recommended to use multiple predictors for the assessment of morphological variables and biomass of land snails, regardless of whether dry or ash free dry biomass is being considered as a response variable (Hawkins et al. 1997). In the present study, the lengthweight relation complies with the allometric equation results (power regression equation was the best fit) as predicted for aquatic snails (Saha et al. 2016; Eklöf et al. 2017). On a comparative scale, S. putris snails were $1.2 \times 1 \mathrm{~mm}$ in SL and SB at birth and reached the size of $9 \mathrm{~mm} \pm 2.6 \mathrm{~mm} \mathrm{SE}$ in SL and $5 \mathrm{~mm} \pm 1.22 \mathrm{~mm} \mathrm{SE}$ in SB after 12 months, though in field conditions, they were $11.3 \mathrm{~mm} \pm 3.03 \mathrm{~mm} \mathrm{SE}$ in SL and $5.2 \mathrm{~mm} \pm 1.01 \mathrm{~mm} \mathrm{SE}$ in SB (Šatkauskiene 2005). At birth, S. thaanumi snails were $0.9 \mathrm{~mm}$ in SL, reaching a maximum of $9.3 \mathrm{~mm}$ $\pm 1.1 \mathrm{~mm} \mathrm{SE}$ at the age of 126 days, and the majority of the cohort exhibited the SL of $7.8 \mathrm{~mm} \pm 1.4 \mathrm{~mm} \mathrm{SE}$ (Rundell and Cowie 2003). As for S. costaricana, at birth they were $0.84 \mathrm{~mm}$ in SL and at the end of the tenth week they reached a SL of $10.69 \mathrm{~mm}$ (Villalobos et al. 1995). The length and breadth of S. baconi (Table 1) was similar to these sizes with the apical angle $\left(\mathrm{AA}^{\circ}\right)$ being 0.67 different from the conical shape of Calliostoma zizyphium snails (Preston and Roberts 2007). In S. ovalis, the soft tissue weight accounted for between 61.9 and $80.5 \%$ of the total weight (Hawkins et al. 1997), while in S. baconi, it accounted for between 68 and 91\% of the total weight with the least weight of shells. The weight of the shells of arboreal snails is low (Watada and Wada 1996), which appeared to be true of S. baconi, in the case of which, the shell weight accounted for between 10 to $30 \%$ of the total weight. The variations in $S$. baconi morphological features determined in this study can, most likely, be linked with ontogeny (Urdy et al. 2010), though plasticity of morphological traits due to habitat conditions cannot be ruled out. Further assessment using the data on $S$. baconi growth should be carried out to validate the proposed relations between weight and length.

Apart from the fragmentary record of snails from West Bengal (Hanley and Theobald 1876; Gude 1914; Ramakrishna and Mitra 2002; Ramakrishna et al. 2010), Karnataka (Mavinkurve et al. 2004; Raheem et al. 2014) and Pillarkan sacred grove in the South Canara belt (Mumbrekar and Madhyastha 2006), research on the population ecology and morphology of the snail $S . b a$ coni has not been carried out to date. Population ecology and life history traits such as body size and fecundity are considered to be crucial parameters for understanding the colonization and spread of land snails (Raut and Ghose1984a, b; Baur 1984; Hawkins et al. 1997; Anderson et al. 2007; Schamp et al. 2010). Considering the information available on land snails in the concerned geographical region including Kolkata (A. fulica Raut 1979, 1999; Raut and Barker 2002; C. ovata Saha and Roy 1994; Avhad et al. 2013; M. indica Raut 1979; A. gracile Raut 1984; Sarma et al. 2007; I. semiserica Raut and Ghose 1984b, Raut 1986; S. daucina Raut et al. 1997), further studies should be carried out to link the patterns of $S$. baconi population growth, fecundity and dispersal to other succineid species in the world (Villalobos et al. 1995; Šatkauskienè 2005; Rundell and Cowie 2003). Along with high vulnerability to the deg- 
radation of habitat conditions, restricted distribution and miscellaneous anthropogenic disturbances cause huge decline in land snail populations (Aravind et al. 2008; Sen et al. 2012). To sustain and enhance the diversity of land snail species (Sen et al. 2012), it is necessary to undertake habitat- and species-based conservation efforts including the development of specific conservation plans for the less known species (Aravind et al. 2008). Therefore, to facilitate the conservation efforts required for the sustenance of snails in the concerned geographical region, studies into the habitat preferences including the plants exploited by $S$. baconi need to be continued.

\section{ACKNOWLEDGEMENT}

The authors acknowledge the constructive comments of the two esteemed reviewers that enabled enhancement of the manuscript to its present form. The language correction by Dr. Laima Monkiené is duly acknowledged. The authors are grateful to the Head, Department of Zoology, University of Calcutta, Kolkata, India for the facilities provided including DST-FIST. HB acknowledges the Principal, Ramnagar College, Depal, Purba Medinipur, India for the facilities provided for the compilation of this work. The financial assistance to GN through UGC, India (Sr. No. 2121430436, Ref. No: 21/12/2014(ii) EU-V, Roll No: 347069, dated 08/06/2015) is duly acknowledged.

Conflict of Interest: As authors of this article, we declare no conflict of interest.

Author's contribution: Conceptualized and compiled by GA, Field observations and collections, HB, Data collection and analysis GN, SP and SB, Statistical analysis GA.

Data availability: The data pertaining to the experiments and results of this article can be made available upon authentic and reasonable request.

\section{REFERENCES}

Addinsoft, S. A. R. L. 2010. XLSTAT software, version 9.0. Paris, France: Addinsoft.

Anderson, T. K., K. F. Weaver, and R. P. Guralnick. 2007. Variation in adult shell morphology and life-history traits in the land snail Oreohelix cooperi in relation to biotic and abiotic factors. Journal of Molluscan Studies 73: 129-137.

Aravind, N. A., R. K. Patil, and N. A. Madhyashtha. 2008. Micromolluscs of the Western Ghats, India: Diversity, distribution and threats. Zoosymposia 1: 281-294.

Avhad, S. B., K. S. Shinde, and C. J. Hiware. 2013. Record of molluscan pest in mulberry gardens in Aurangabad district of Maharashtra state, India. Indian Journal of Sericulture 52 (1): 29-33.

Barker, G. M. 2001. Biology of terrestrial Molluscs. CAB Wallingford, UK. xiv $+558 \mathrm{pp}$.

Barker, G. M. 2002. Molluscs as crop pest. CAB Wallingford, UK.xii +468 pp.

Baur, B. 1984. Shell size and growth rate differences for alpine populations of Arianta arbustrum (L.) (Pulmonata; Helicidae). Revue Suisse Zoology 91: 37-46.

Bledose, M. E., and D. R. Minnick. 1982. Citrus tree snail and suppression of citrus microbiota. Environmental Entomology 11: 1091-1095.

Budha, P. B., F. Naggs, and T. Backeljau. 2015. Annotated checklist of the terrestrial gastropods of Nepal. ZooKeys 492: $1-48$.

Cain, A. J. 1977. Variation in the spire index of some coiled gastropods shell, and its evolutionary significance. Philosophical Transaction of the Royal society of London.Series B (277): 377-428.

Cameron, R. A. D., and L. M. Cook. 1989. Shell size and shape in Madeiran land snails: do niches remain unfilled? Biological Journal of the Linnaean Society 36: 79-96.

Carvalho, C. D. M., E. C. D. A. Bessa, and S. D’ávila. 2008. Life history strategy of Bradybaena similaris (Fèrussac, 1821) (Mollusca, Pulmonata, Bradybaenidae). Molluscan Research 28 (3): 171-174.

Chiba, S. 2005. Appearance of morphological novelty in a hybrid zone between two species of land snail. Evolution 59 (8): 462-470.

Craig, A. K. 1972. Observations on the arboreal snail Orthalicus floridensis. Quarternary Journal of the Florida Academy of Sciences 35 (1): 15-20.

Das, S. K., S. Nandi, R. Sompomu, and G. SubbaRao. 1989. Two new snail pests, Cyclophorus fulguratus (Pfeiffer) and Cryptaustenia ovata (Blanford) of mulberry plants of Kalimpong. Indian Journal of Sericulture 28 (2): 267-268.

Eklöf, J., A. Austin, U. Bergström, S. Donadi, B. D. H. K. Eriksson, J. Hansen, and G. Sundblad. 2017. Size matters: relationships between body size and body mass of common coastal, aquatic invertebrates in the Baltic Sea. Peer J 5:e2906.

Elkarmi, A. Z., and N. S. Ismail. 2007. Growth models and shell morphometrics of two populations of Melanoides tuberculata (Thiaridae) living in hot springs and freshwater pools. Journal of Limnology 66 (2): 90-96.

Fox, J. 2008. Applied regression analysis and generalized linear models. Sage Publications, Inc., 688 p.

Goodfriend, G. A. 1986. Variation in land-snail shell form and size and its causes: a review. Systematic Biology 35 (2): 204-223.

Gude, G. K. 1914. The Fauna of the British India, Including Ceylon and Burma. Mollusca-II. London: Taylor and 
Francis, 540 pp.

Hanley, S., and W. Theobald. 1876. Conchologia India: Illustration of the Land and Fresh Water Shells of British India. London, England: L. Reeve and Co. 68 p. + 50 plates.

Hawkins, J. W., M. Lankester, and R. A. Lautenschlager. 1997. Length-biomass and energy relationships of terrestrial gastropods in northern forest ecosystems. Canadian Journal of Zoology 75 (3): 501-505.

Hurlbert, S. H. 1984. Pseudoreplication and the design of ecological field experiments. Ecological Monographs 54 (2): 187-211.

Kasigwa, P. F. 1999a. Dispersion factors in the arboreal snail Sitala jenynsi (Gastropoda: Ariophantidae). South African Journal of Zoology 34 (4): 145-153.

Kasigwa, P. F. 1999b. Snail arboreality: the microdistribution of Sitala jenynsi (Gastropoda: Ariophantidae). South African Journal of Zoology 34 (4): 154-162.

Ludwig, J. A., and J. F. Reynolds. 1988. Statistical ecology: a primer on methods and computing. New York, USA: John Wiley \& Sons. 337 pp.

Madec, L., and A. Bellido. 2007. Spatial variation of shell morphometrics in the subantarctic land snail Notodiscus hookeri from Crozet and Kerguelen Islands. Polar Biology 30: 1571-1578.

Madec, L. A., A. Bellido, and A. Guiller. 2003. Shell shape of land snail Cornu aspersum in North Africa: unexpected evidence of phylogeographical splitting. Heredity 91: 224-231.

Mavinkurve, R. G., S. P. Shanbhag, and N. A. Madhyashta. 2004. Checklist of terrestrial Gastropods of Karnataka, India. Zoos ' Print Journal 19 (11): 1684-1686.

McCullagh, P., and J. A. Nelder. 1989. Generalized linear models. Second Edition. London, UK: Chapman and Hall, 532 pp.

McKinney, R. A., S. M. Glatt, and S. R. Williams. 2004. Allometric length-weight relationships for benthic prey of aquatic wildlife in coastal marine habitats. Wildlife Biology 10 (1): 241-249.

Mumbrekar, K. D., and N. A. Madhyastha. 2006. Land molluscs of Pillarkan sacred grove. Zoo's Print Journal 21 (6): 2295.

Nandy, G., H. Barman, S. Pramanik, K. Paul, D. Kundu, and G. Aditya. 2019. Observations on the predation of the snail Huttonella bicolor on the snail Allopeas gracile. Zoology and Ecology 29 (2): 131-136.

Okon, B., L. A. Ibom, H. E. Ettah, and U. H. Udah. 2012. Comparative differentiation of morphometric traits and body weight prediction of giant African snails with four whorls in Niger Delta region of Nigeria. Journal of Agriculture Science 4 (10): 205-211.

Palmer, A. R. 1982. Growth in marine gastropods: a nondestructive technique for independently measuring shell and body weight. Malacologia 23 (1): 63-73.

Panha, S., and J. B. Burch. 2005. An introduction to the micro- snails of Thailand. Malacological Review 37/38: 1-155.

Preston, S. J., and D. Roberts. 2007. Variation in shell morphology of Calliostoma zizyphinum (Gastropoda: Trochidae). Journal of Molluscan Studies 73: 101-104.

Raheem, D. C., and F. Naggs. 2006. An illustrated guide to the land snails of Sri Lankan natural forest and cultivated habitats. London: Natural History Museum.

Raheem, D. C., H. Taylor, J. Ablett, R. C. Preece, N. A. Aravind, and F. Naggs. 2014. A Systematic Revision of the land snails of the Western Ghats of India. Tropical Natural History Suppl. 4: 1-294.

Ramakrishna, and S. C. Mitra. 2002. Endemic land molluscs of India. Records of the Zoological Survey of India, Occasional paper 196: 1-65.

Ramakrishna, S. C. Mitra, and A. Dey. 2010. Annotated checklist of Indian land molluscs. Kolkata, India: Zoological Survey of India, $344 \mathrm{pp}$.

Rao, H.S. 1924. Asiatic Succineidae in the Indian Museum. Records of the Indian Museum 26: 367-407.

Raut, S. K. 1979. Distribution and population of two snail Achatina fulica, Bowdich and Macrochlamys indica (Godwin-Austien). Bulletin of Zoological Survey of India 13: 91-96.

Raut, S. K. 1984. Breeding season of the garden snail Opeas gracile (Hutton) (Gastropoda: Subulinidae). Journal of Zoological Society of Japan 36 (1-2): 89-94.

Raut, S. K. 1986. Destruction of Indosuccinea semiserica (Gastropoda: Succineidae) eggs by the beetle Cryptobium fluviatile. Malacological Review 19 (1-2): 105.

Raut, S. K. 1999. The giant African land snail Achatina fulica Bowdich in Nepal and Bhutan. Journal of the Bombay Natural History Society 96 (1): 173.

Raut, S. K., and K. C. Ghose. 1984a. Pestiferous land snails of India. Zoological Survey of India 11 (1-151). Calcutta, Bani Press.

Raut, S. K., and K. C. Ghose.1984b. Natural history of a Succineid snail, Indosuccinea semiserica (Gould). Bulletin of the Zoological Survey of India 5 (2, 3): 191-193.

Raut, S. K., and G. Barker. 2002. Achatina fulica Bowdich and others Achatinidae pest in tropical agriculture. In Molluscs as Crop Pest, edited by Barker, G., 55-114. New Zealand, Hamilton: CAB Publishing.

Raut, S. K., T. K. Misra, and S. Das. 1997. Life-history of a succineid snail Succinea daucina (Pfeiffer). Journal of the Bombay Natural History Society 94: 589-591.

Rundell, R. J., and R. H. Cowie. 2003. Growth and reproduction in Hawaiian succineid land snails. Journal of Molluscan Studies 69: 288-289.

Saha, T. C., and S. P. Roy. 1994. Egg nesting behaviour, clutch size and hatching of eggs of two hill pulmonates Macrochlamys tugurium (Benson) and Cryptaustenia ovata (Blanford) (Mollusca: Gastropoda). Journal of Bengal Natural History Society 13 (2): 15-22.

Saha, C., S. Pramanik, J. Chakraborty, S. Parveen, and G. Aditya. 2016. Abundance and body size of the in- 
vasive snail Physa acuta occurring in Burdwan, West Bengal, India. Journal of Entomology and Zoology Studies 4 (4): 490-497.

Sajan, S. K., S. Das, B. Tripathy, and T. Biswas. 2021. Malacofaunal inventory in Chintamoni Kar Bird Sanctuary, West Bengal, India. Journal of Threatened Taxa 13 (2): 17807-17826.

Sarma, K., R. Tandon, K. R. Shivanna, and H. Y. Mohan Ram. 2007. Snail-pollination in Volvulopsis nиттиlarium. Current Science 93 (6): 826-831.

Schamp, B., M. Horsák, and M. Hájeck. 2010. Deterministic assembly of land snail communities according to species size and diet. Journal of Animal Ecology 79: 803-810.

Sen, S., G. Ravikanth, and N. A. Aravind. 2012. Land snails (Mollusca: Gastropoda) of India: status, threats and conservation strategies. Journal of Threatened Taxa 4 (11): 3029-3037.

Stone, J. R. 1996. Computer simulated shell size and shape variation in the carabian land snail genus Cerion: A test of geometrical constraints. Evolution 50 (1): 341-347.

Sturm, C. F., T. A. Pearce, and A. Valdes. 2006. The Mollusks: A guide to their study, collection and preservation. American Malacological Society, Pittsburg, PA, USA, $445 \mathrm{pp}$.

Sugiura, S. 2011. Diverse plant taxa used by arboreal succineid snails as microhabitats. Journal of Natural History 45: 23-24.

Šatkauskienè, I. 2005.Characteristic of lifespan and repro- duction period of Succinea putris (L.) (Gastropoda: Styllomatophora). Ekologija 3: 28-33.

Takeuchi, M., and Y. Takeda. 2016. Dependence of the endangered arboreal snail Satsuma (Luchuhadra) eucosmia eucosmia (Camaenidae) on Ficus (Moraceae) trees as its main habitat. Molluscan Research 36 (4): 231-238.

Tokeshi, M., N. Ota, and T. Kawai. 2000. A comparative study of morphometry in shell-bearing Mollusks. Journal of Zoology 251: 31-38.

Urdy, S., N. Goudemand, H. Bucher, and R. Chirat. 2010. Growth-dependent phenotypic variation of molluscan shells: implications for allometric data interpretation. Journal of Experimental Zoology (Molecular and Developmental Evolution) 314B: 303-326.

Villalobos, M. C., J. Monge-Najera, Z. Barrientos, and J. Franco. 1995. Life cycle and field abundance of the snail Succinea costaricana (Stylommatophora: Succineidae), a tropical agricultural pest. Revista de Biologia Tropical 43 (1-3): 181-188.

Watada, H., and K. Wada. 1996. Arboreal distribution of the land snail Euhadra amaliae. Venus 55:123-137.

Watada, H., and K. Wada. 1998. Tree species preference of the arboreal snail Euhadra amaliae. Venus 57: 29-37.

Wilson, M. J. 2007.Terrestrial mollusc pests.In Field Manual Techniques in Invertebrate Pathology, edited by Lawrence, L.A., and H. Kaya,751-765. The Netherlands: Springer, Dordrecht.

Zar, J. H. 1999. Biostatistical Analysis. IV ed. New Delhi, India: Pearson Education Singapore Pte. Ltd., Indian Branch, 663 pp. 